\title{
CONVERSION OF MODIFIED FONTAN PROCEDURE TO LATERAL ATRIAL TUNNEL CAVOPULMONARY ANASTOMOSIS
}

Jacqueline Kreutzer, MD

John F. Keane, MD

James E. Lock, MD

Edward P. Walsh, MD

Richard A. Jonas, MD

Aldo R. Castañeda, MD, PhD

John E. Mayer, Jr., MD
After modified Fontan procedures with atriopulmonary anastomoses or right atrium-right ventricle conduits, some patients have progressive exercise intolerance, effusions, arrhythmias, or protein-losing enteropathy. Theoretic advantages of a lateral atrial tunnel cavopulmonary anastomosis and published clinical results suggest that conversion of other Fontan procedures to the lateral atrial tunnel may afford clinical improvement for some patients. Eight patients ( 8 to 25 years old) with tricuspid atresia $(n=$ 4), double-inlet left ventricle $(n=3)$, and double-outlet right ventricle $(n=$ 1) underwent conversion to a lateral tunnel procedure between December 1990 and November 1994. An arbitrary clinical score was assigned before the lateral tunnel procedure and at follow-up. Before conversion, patients had decreased exercise tolerance $(n=8)$, arrhythmias $(n=6)$, effusions $(n=4)$, and protein-losing enteropathy $(n=8)$. At catheterization, all had a low cardiac index $\left(1.9 \pm 0.7 \mathrm{~L} \cdot \min ^{-1} \cdot \mathrm{m}^{-2}\right)$, five had elevated pulmonary vascular resistance ( $>3$ Wood units), and three had right pulmonary venous return obstruction by compression of an enlarged right atrium. Fenestrated lateral tunnel construction was undertaken $7.3 \pm 3.6$ years after atriopulmonary anastomosis, with one early death related to low cardiac output. After the lateral tunnel procedure, two patients had no clinical improvement (no change in clinical score) but five patients had either marked or partial improvement. The right pulmonary vein compression present in three patients was resolved after conversion. The mean clinical scores improved from $4.5 \pm 1$ to $3.0 \pm 2(p<0.04)$. In conclusion, conversion to a lateral tunnel procedure led to clinical improvement in five of eight patients at short-term follow-up and may be particularly indicated for patients with giant right atria or pulmonary vein compression who have symptoms. Pulmonary vein compression should be looked for in patients after modified Fontan procedures and can be relieved by conversion to the lateral tunnel procedure. (J Thorac Cardiovasc Surg 1996;111:1169-76)
A fter modified Fontan procedures, such as right atrium-right ventricle conduit or atriopulmonary anastomosis (APA), some patients have progressive exercise intolerance, atrial arrhythmias, chronic effusions, or protein-losing enteropathy. ${ }^{1-6}$ The non-

From the Departments of Pediatrics and Surgery, Harvard Medical School, and the Departments of Cardiology and Cardiovascular Surgery, Children's Hospital, Boston, Mass.

Received for publication May 3, 1995; revisions requested Oct. 2, 1995; revisions received Nov. 2, 1995; accepted for publication Nov: 7, 1995.

Address for reprints: Jacqueline Kreutzer, MD, Department of Cardiology, Children's Hospital, 300 Longwood Ave., Boston, MA 02115 .

Copyright $(\mathcal{C} 1996$ by Mosby-Year Book, Inc.

$0022-5223 / 96 \$ 5.00+0 \quad \mathbf{1 2} / \mathbf{1} / \mathbf{7 0 5 3 7}$ laminar venous blood flow that results from the postsurgical anatomy may cause energy loss, as suggested by experimental studies, 7,8 and it may result in low cardiac output and development of symptoms. In addition, markedly enlarged right atria may also compress the pulmonary veins, causing elevated resistance to pulmonary blood flow.

Few therapeutic options have been considered for patients with such problems. Cardiac catheterization may identify anatomic or hemodynamic abnormalities in their circulation, some of which can be corrected either by transcatheter techniques or surgically. ${ }^{10-12}$ Heart transplantation is often a consideration, ${ }^{13-15}$ particularly if ventricular dysfunction is present. When ventricular function is preserved, conversion to a lateral tunnel Fontan procedure 
Table I. Clinical score

\begin{tabular}{llll}
\hline \multicolumn{1}{c}{ Clinical feature } & \multicolumn{1}{c}{ o points } & \multicolumn{1}{c}{1 point } & \multicolumn{1}{c}{2 points } \\
\hline Exercise tolerance & No limitations (NYHA class I) & Slight limitation (NYHA class II) & Severe limitation (NYHA class III or IV) \\
Arrhythmias & None on no medications & None on medications or after & Arrhythmias on medications or after RFA \\
& & RFA & Chronic \\
Effusions & None & Intermittent & Yes \\
PLE & No & &
\end{tabular}

$N Y H A$, New York Heart Association congestive heart failure classification; $R F A$, radiofrequency ablation; $P L E$, protein-losing enteropathy.

(LT) has been recently proposed, ${ }^{9}$ although indications and possible predictors of success for such a procedure are unknown. The purpose of this report is to describe our experience with eight patients with marked symptoms who underwent conversion from atriopulmonary or atrioventricular Fontan operations to LT.

\section{Methods}

Patient population. Before 1989, 245 patients at our institution underwent modified Fontan procedures with APA or right atrium-right ventricle conduits. Between December 1990 and November 1994, eight of these patients had the initial Fontan connection converted to LT; these patients constitute the study group. The age at conversion to LT ranged from 7.9 to 25 years $(14.3 \pm 6.8$ years). The interval between the original Fontan procedure and the conversion procedure was $7.3 \pm 3.6$ years, ranging from 3 to 13 years. There were four male and four female patients.

Data collection and follow-up. All available data, including medical records, operative notes, cardiac catheterizations, electrocardiograms, echocardiograms, and lung perfusion scans, were reviewed. Lung scans before and after conversion were obtained only for three patients in whom right pulmonary vein stenosis resulting from extrinsic compression by a "giant" right atrium was identified. An arbitrary clinical score (Table I) was assigned to each patient before conversion and at the latest follow-up. Four clinical features were considered as components of the score: (1) exercise tolerance, (2) arrhythmias, (3) effusions, and (4) protein-losing enteropathy. A maximum of 2 points was assigned for each feature, with a higher clinical score indicating a worse clinical condition.

Exercise tolerance. Exercise tolerance was graded according to the New York Heart Association classification for congestive heart failure. In addition, three patients also had exercise testing performed.

Arrhythmias. For evaluation of arrhythmias, clinical history and electrocardiograms were available in all cases, and Holter recordings before and after conversion were available for five and six patients, respectively. Intracardiac electrophysiologic studies were performed in two patients before conversion and in another two after conversion, at which time mapping of the atrial flutter circuits was performed. One of these patients underwent radiofrequency ablation.

Effusions. Effusions were considered to be present only when patients required hospitalization for drain- age (chest tube placement, pericardioscentesis) or high doses of diuretic therapy (furosemide at more than 3 $\mathrm{mg} \cdot \mathrm{kg}^{-1} \cdot \mathrm{day}^{-1}$ ). If effusions persisted for more than 3 weeks after onset of therapy, they were classified as chronic; if they were of shorter duration but recurred at least twice in the course of a 6 -month period, they were considered intermittent.

Protein-losing enteropathy. Protein-losing enteropathy was considered to be present with a serum albumin concentration of less than $2 \mathrm{gm} / \mathrm{dl}$ on more than three separate determinations and a requirement for albumin replacement therapy at least once every 3 months.

Operative technique. All the patients had the original Fontan connection replaced by LT with a $4 \mathrm{~mm}$ fenestration.

Statistical analysis. The numeric data are expressed as mean \pm standard deviation. The Wilcoxon signed-rank test was used to compare clinical scores before and after conversion to LT.

\section{Results}

Patient characteristics. Descriptive data are summarized in Table II. The diagnoses were tricuspid atresia (four patients), double-inlet left ventricle (three patients), and double-outlet right ventricle with multiple ventricular septal defects (one patient). Before APA, all had undergone previous palliative procedures including Blalock-Taussig shunts (three patients), Glenn shunts (two patients), or pulmonary artery banding (four patients). Five patients had been considered to be at high risk as Fontan candidates when APA was performed because of elevated pulmonary vascular resistance (two patients), pulmonary artery distortion (three patients), systemic venous abnormality (one patient), or moderate atrioventricular valve regurgitation (one patient). None had clinical arrhythmias before the initial modified Fontan procedure.

At the time of the conversion operation, all patients had decreased exercise tolerance of New York Heart Association functional class II, III, or IV. Six had arrhythmias involving recurrent intraatrial reentry (flutter or fibrillation), and one patient had an atrial pacemaker implanted for sinus node dysfunction. 

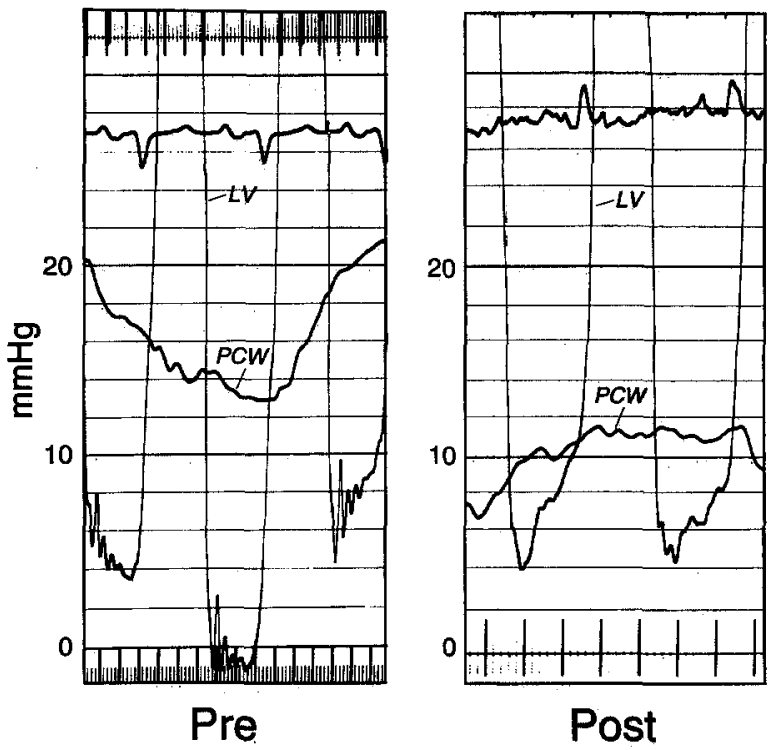

Fig. 1. Pressure tracings recorded at cardiac catheterization before conversion to LT (Pre) and after conversion (Post). Note the gradient between the pulmonary capillary wedge pressure $(P C W)$ and the ventricular end-diastolic pressure $(L V)$. After conversion to LT (Post), cardiac catheterization hemodynamics demonstrate resolution of pulmonary vein stenosis gradient.

Effusions were present in four patients. Three patients had ascites and pleural effusions and one had pleural and pericardial effusions. Two patients had protein-losing enteropathy necessitating longterm albumin replacement therapy. One patient had an atrial thrombus eight months before conversion; this condition was managed medically with complete resolution by the time of LT.

Cardiac catheterization. Preoperative cardiac catheterization was performed in all cases (Table II). Pulmonary artery mean pressures were higher than $16 \mathrm{~mm} \mathrm{Hg}$ in six patients (median $18.3 \pm 4.6$ $\mathrm{mm} \mathrm{Hg}$ ). The median pulmonary vascular resistance was $4.8 \pm 4.2$ Wood units, and it exceeded 3 Wood units in five patients. All had low cardiac index (mean $1.9 \pm 0.7 \mathrm{~L} \cdot \mathrm{min}^{-1} \cdot \mathrm{m}^{-2}$ ). Obstruction of the right pulmonary venous return as a result of compression by a markedly dilated right atrium was diagnosed in three patients, with an average gradient of $10 \mathrm{~mm} \mathrm{Hg}$ (Fig. 1). The pulmonary vein compression was demonstrated hemodynamically and by angiography in all cases as well as by chest magnetic resonance imaging in one (Fig. 2). Lung scintigraphy showed decreased perfusion of the right lung compared to the left.
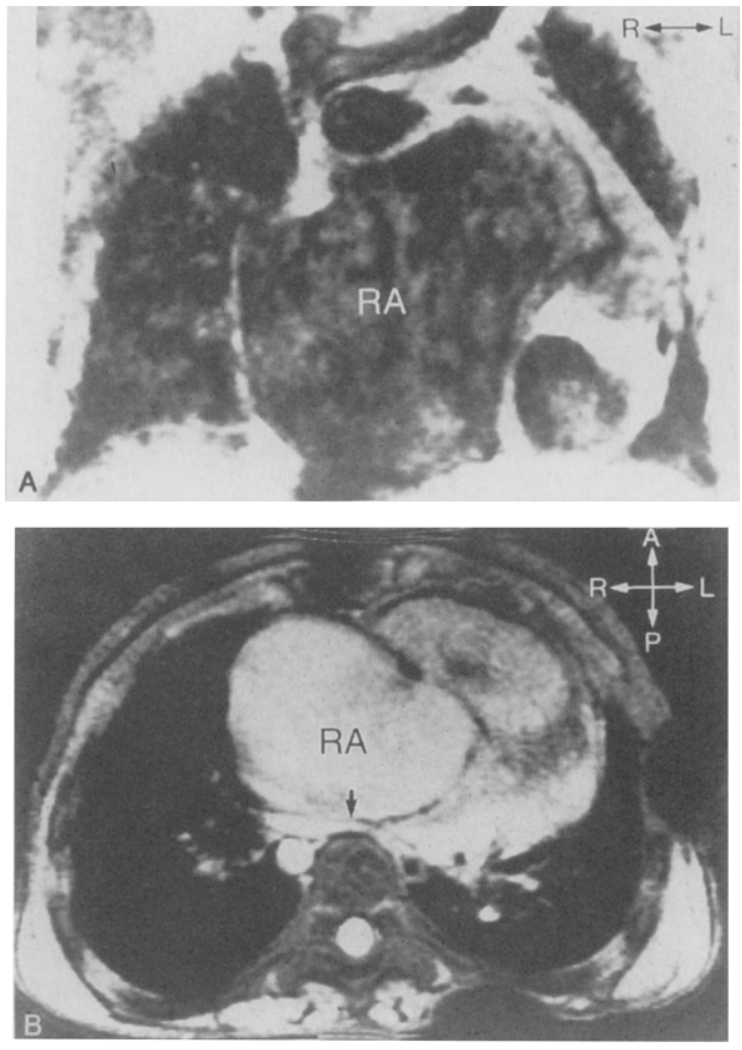

Fig. 2. Chest magnetic resonance imaging in orthogonal (A) and transaxial (B) views show a giant right atrium after atriopulmonary anastomosis, before conversion to LT. Note the compression of the right pulmonary veins (arrow) against the spine by the posterior wall of the right atrium $(R A)$ in part $\mathbf{B}$.

Only one patient had elevated left ventricular end-diastolic pressure but preserved systolic ventricular function, in association with severe subaortic stenosis as a result of a restrictive bulboventricular foramen. In six patients, there was no significant gradient across the APA. Two patients, with right atrium-pulmonary artery and right atrium to right ventricle conduits had mean gradients of $4 \mathrm{~mm} \mathrm{Hg}$ and $8 \mathrm{~mm} \mathrm{Hg}$, respectively. Two stents had previously been placed in two of the conduits, decreasing the gradient. $^{16}$

Surgical LT procedure. The period between APA and conversion to LT was $7.3 \pm 3.6$ years ( 3 to 13 years). All patients underwent conversion to a fenestrated LT with polytetrafluoroethylene patch,* leaving minimal RA wall exposed to high pressures.

\footnotetext{
*Gore-Tex patch and tube, registered trademark of W. L. Gore \&
} Associates, Inc., Newark, Del. 
Table II. Patient characteristics

\begin{tabular}{|c|c|c|c|c|c|c|c|}
\hline $\begin{array}{l}P_{t} \\
\text { no. }\end{array}$ & Diagnoses & $\begin{array}{l}\text { Previous } \\
\text { operations }\end{array}$ & APA connection & $\begin{array}{c}\text { Age at } \\
\text { APA (yr) }\end{array}$ & $\begin{array}{c}\text { Age at } L T \\
(y r)\end{array}$ & $\begin{array}{c}\text { Other } \\
\text { procedures }\end{array}$ & $\begin{array}{c}\text { NYHA class } \\
\text { before } L T\end{array}$ \\
\hline 1 & DORV, MVSDs & $\mathrm{PAB}$ & $\begin{array}{l}\text { SVC-MPA, TV closure, } \\
\text { ASD closure }\end{array}$ & 5 & 8.8 & SAS resection & III \\
\hline 2 & Single DILV, BVF & Left BTS & $\begin{array}{l}\text { RA to MPA nonvalved } \\
\text { conduit, TV patch }\end{array}$ & 5.2 & 16 & - & IV \\
\hline 3 & $\begin{array}{l}\text { TA, TGA, restrictive } \\
\text { VSD, JAA }\end{array}$ & $\begin{array}{l}\text { Right BTS, PA } \\
\text { plasty }\end{array}$ & $\begin{array}{l}\text { APA, ASD closure, } \\
\text { BVF resection }\end{array}$ & 2.4 & 8.5 & - & III \\
\hline 4 & TA, restrictive VSD & Right BTS & $\begin{array}{l}\text { RA to RV valved con- } \\
\text { duit, VSD and ASD } \\
\text { closure }\end{array}$ & 11 & 24 & - & IV \\
\hline 5 & Single DILV & $\mathrm{PAB}$ & $\begin{array}{l}\text { APA, TV suprannular } \\
\text { patch closure, ASD } \\
\text { closure }\end{array}$ & 3 & 7.9 & SAS resection & II \\
\hline 6 & $\begin{array}{l}\text { TA, TGA, restrictive } \\
\text { VSD }\end{array}$ & $\begin{array}{l}\text { PAB, right } \\
\text { Glenn }\end{array}$ & $\begin{array}{l}\text { APA, fenestrated ASD } \\
\text { closure }\end{array}$ & 9 & 12 & - & II \\
\hline 7 & TA, restrictive VSD & Right Glenn & $\begin{array}{l}\text { RA to MPA conduit, } \\
\text { ASD closure }\end{array}$ & 15 & 25 & $\begin{array}{l}\text { PA plasty } \\
\text { (GTX) }\end{array}$ & III \\
\hline $\begin{array}{c}8 \\
\text { Mean }\end{array}$ & Single DILV & $\mathrm{PAB}$ & APA, atrial patch & $\begin{array}{c}4.6 \\
6.9 \pm 4.4\end{array}$ & $\begin{array}{c}11 \\
14.3 \pm 6.8\end{array}$ & DKS & II \\
\hline
\end{tabular}

$A P A$, Atriopulmonary anastomosis or initial modified Fontan procedure; NYTLA. New York Heart Association congestive heart failure classification; PVR, pulmonary vascular resistance (Wood units); $C I$, cardiac index $\left(\mathrm{L} \cdot \mathrm{min}^{-1} \cdot \mathrm{m}^{-2}\right) ; V E D P$, systemic ventricular end-diastolic pressure (mm $\mathrm{Hg}$ ); $R A P$, right atrial pressure $(\mathrm{mm} \mathrm{Hg}) ; P V S$, pulmonary vein stenosis mean gradient (mm $\mathrm{Hg}$ ); DORV, double-outlet right ventricle; $M V S D$ s, multiple ventricular septal defects; $P A B$, pulmonary artery banding; $S V C-M P A$, superior vena cava-main pulmonary artery; $T V$, tricuspid valve; $A S D$, atrial septal defect; $S A S$, subaortic stenosis; $D I L V$, double-inlet left ventricle; $B V F$, bulboventricular foramen; $B T S$, Blalock-Taussig shunt; RA, right atrium; $M P A$, main pulmonary artery; $T A$, tricuspid atresia; $T G A$, transposition of the great arteries; $V S D$, ventricular septal defect; $J A A$, juxtaposition of the atrial appendages; $P A$, pulmonary artery; $R V$, right ventricle; $G T X$, pulmonary artery reconstruction with interposition of polytetrafluoroethylene tube; $D K S$, Damus-Kay-Stansel procedure.

*Fenestration closed at follow-up.

†Average gradient in three patients with PVS by compression.

Additional surgical procedures performed were closure or takedown of APAs, takedown of conduits and a previously implanted stent, atrial septectomy, closure of a tricuspid valve leak, subaortic resection for a restrictive bulboventricular foramen $(n=2)$ and main pulmonary artery to aortic anastomosis for subaortic obstruction $(n=1)$. One patient required interposition of a polytetrafluoroethylene tube* between discontinuous left and main pulmonary arteries.

Postoperative results and follow-up. One early death occurred on the fourth postoperative day related to elevated pulmonary vascular resistance, low cardiac index, and atrial arrhythmias (Table II; patient 4). The seven survivors were followed up for $23 \pm 15$ months ( 3 to 42 months). On the basis of the clinical score analyses (Fig. 3), three patients had marked clinical improvement, two patients had evidence of some improvement, and two patients remained unchanged. The average mean clinical score was $4.5 \pm 1$ before conversion and decreased to $3.0 \pm 2$ after conversion. The difference between the two was statistically significant by Wilcoxon signed-rank test $(p<0.04)$.

${ }^{*}$ Gore-Tex patch and tube, registered trademark of W. L. Gore \& Associates, Inc., Newark, Del.
Exercise tolerance. All patients had decreased exercise tolerance before conversion, with New York Heart Association classes II (three patients), III (three patients), and IV (two patients, Table II). After conversion, six patients had either marked or partial improvement in the exercise tolerance. Five patients had improvement by one class and one patient had improvement by two classes.

Protein-losing enteropathy. Neither of the two patients with protein-losing enteropathy had improvement of this condition. One patient underwent cardiac transplantation at another institution as a result of persistent protein-losing enteropathy similar in severity to the preoperative condition. The remaining patient continues to require weekly albumin infusions at follow-up.

Effusions. Only one of four patients with chronic effusions had improvement of this condition. Ascites or pleural effusions persisted in the other three.

Arrhythmias. Of the six patients with atrial arrhythmias before conversion, only two are arrhythmia free (one on a regimen of digoxin and one without any antiarrhythmic medications). The patient who died in the early postoperative period had 


\begin{tabular}{|c|c|c|c|c|c|c|c|c|}
\hline \multirow{2}{*}{$\begin{array}{c}\text { Score } \\
\text { before } L T\end{array}$} & \multicolumn{5}{|c|}{ Catheterization characteristics before $L T$} & \multirow{2}{*}{$\begin{array}{c}\text { Score } \\
\text { after } L T\end{array}$} & \multirow{2}{*}{$\begin{array}{c}\text { NYHA class } \\
\text { after } L T\end{array}$} & \multirow{2}{*}{$\begin{array}{c}\text { Follow-up } \\
\text { (mo) }\end{array}$} \\
\hline & PVR & $C I$ & $V E D P$ & $R A P$ & PVS & & & \\
\hline 6 & 3.3 & 1.7 & 10 & 15 & 0 & 6 & III & 42 \\
\hline 7 & 1.5 & 2.8 & 10 & 16 & 0 & 7 & III & 26 \\
\hline 4 & 2.9 & 2.5 & 8 & 22 & 8 & 2 & $\mathrm{I}(\#)$ & 38 \\
\hline 6 & 3.4 & 1.5 & 12 & 17 & 0 & 6 & dead & - \\
\hline 3 & 2.2 & 2.7 & 10 & 12 & 0 & 0 & I & 28 \\
\hline 3 & 14.5 & 1.1 & 6 & 22 & 12 & 0 & $I(\#)$ & 18 \\
\hline 4 & 7.2 & 1 & 10 & 16 & 10 & 2 & II (\#) & 5 \\
\hline 3 & $\begin{array}{c}3.5 \\
4.8 \pm 4.2\end{array}$ & $\begin{array}{c}2 \\
1.9 \pm 0.7\end{array}$ & $\begin{array}{c}16 \\
10.3 \pm 2.1\end{array}$ & $\begin{array}{c}26 \\
18.3 \pm 4.6\end{array}$ & $\begin{array}{c}0 \\
10^{*}\end{array}$ & 1 & 1 & $\begin{array}{c}3 \\
23 \pm 15\end{array}$ \\
\hline
\end{tabular}

recurrent atrial tachycardia before death. Of the remaining three patients with recurrent tachycardia, one underwent successful radiofrequency catheter ablation of a flutter circuit and two patients continue on regimens of medications.

Pulmonary vein compression. All three patients with pulmonary vein compression before conversion had clinical improvement after LT. In all cases, resolution of the gradient was confirmed by echocardiography and at cardiac catheterization. Although lung perfusion scans are difficult to interpret in patients with modified Fontan procedures as a result of incomplete mixing of the venous blood and streaming, two patients with preoperative preferential perfusion of the left lung now have preferential perfusion of the right lung after conversion to LT.

Thrombotic events. One patient with a complex surgical connection had a large intracardiac thrombus in the intraatrial baffle and left pulmonary artery polytetrafluoroethylene tube. It was managed with surgical thrombectomy and long-term oral anticoagulants and there has been no recurrence to date. No other thromboembolic event was observed after conversion to LT.

Oxygen saturation and fenestration. Among the seven survivors after conversion, the fenestration has been closed in three: by transcatheter clamshell closure in one (in whom a large baffle suture line defect was also similarly closed), intraoperative closure in another, and spontaneously in the remaining patient. The average oxygen saturation for these three patients is $93 \%$. Of the four patients with an open fenestration, two continue to have symptoms and are without clinical improvement; the other two have improvement, and transcatheter closure of the fenestration is anticipated.

\section{Discussion}

Since the initial reports for repair of tricuspid atresia by Fontan and Baudet ${ }^{17}$ and Kreutzer and associates, ${ }^{18,19}$ the lesions so treated have increased greatly and many modifications have been developed $^{20-28}$ in an attempt to create a hemodynamically optimal right heart connection.

The total cavopulmonary connection with LT was initially proposed by Puga, Chiavarelli, and $\mathrm{Hagler}^{29}$ and by Jonas and Castañeda ${ }^{30}$ as an alternative to APA, particularly in the case of complex Fontan operations, such as for patients with left atrioventricular valve atresia or single atrioventricular valve. Several potential advantages became apparent: (1) the procedure was technically simple and reproducible in any atrioventricular arrangement, and (2) maintenance of low pressure is possible in most of the right atrium and coronary sinus, with possible improvement in the incidence of atrial arrhythmias. Subsequently, hydrodynamic studies performed by de Leval and coworkers ${ }^{7}$ suggested that the right atrium is not an efficient pump in nonvalved APA and that atrial pulsations could generate turbulence, leading to a higher energy loss. A reduction of energy loss as a result of lessened turbulence in the 


\section{Pre-Post Fontan Conversion Scores}

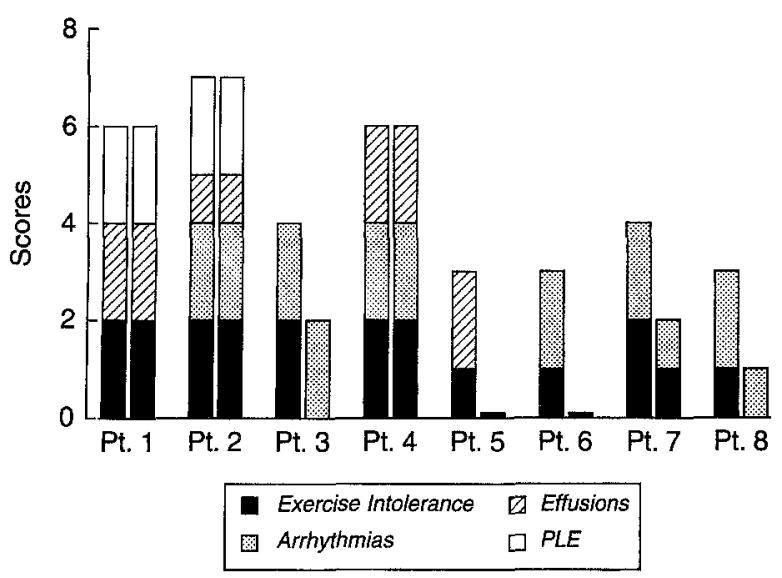

Fig. 3. Bar graph illustrating clinical scores assigned to each patient before and after conversion at the latest follow-up, according to the arbitrary scoring system summarized in Table I. Each patient was assigned two bars, ranging from 0 points to 8 points, representing clinical scores both before (first bar) and after (second bar) conversion to LT. PLE, Protein-losing enteropathy.

LT potentially would decrease the incidence of atrial thrombosis or even increase the cardiac index. In addition, other experimental studies with animal models $^{31,32}$ supported the concept that the atrial contraction is not essential to the maintenance of pulmonary blood flow in a total right heart bypass operation. In vitro flow studies have also suggested that the total energy loss in a cavopulmonary model may be less than that seen in an atriopulmonary model, ${ }^{8,33}$ although the magnitude of these losses is small. Published clinical results of different modified Fontan procedures tend to favor the total cavopulmonary anastomosis, or LT Fontan procedure, as the variation with lowest incidence of late atrial arrhythmias. ${ }^{3,5,6,26}$ It is necessary to recognize the limitations of retrospective studies and the marked differences in follow-up periods for the different techniques. At present, the procedure of choice in many centers consists of a lateral intraatrial tunnel type of total cavopulmonary anastomosis, with or without a fenestration.

A recent report by Kao and colleagues ${ }^{9}$ on conversion of APA to cavopulmonary anastomosis in three patients operated on during 1993 and followed up for 8 months suggests that surgical conversion could be used for the management of atrial arrhythmias or acute atrial thrombosis. In our series, only one patient had had a thrombotic episode before conversion; this was managed medically and had resolved by conversion. One patient who required a complex LT connection with interposition of a polytetrafluoroethylene tube between the left pulmonary artery and the main pulmonary artery had a thrombosis necessitating surgical thrombectomy after conversion to LT. Our series suggests that conversion does not necessarily eliminate the risk of acute thrombosis, particularly when a complex connection is required.

Conversion to LT seems to have been a beneficial surgical option for some of our eight patients who had symptoms after APA or other modified Fontan procedures, in which most of the right atrium was exposed to high pressures. The patients with protein-losing enteropathy did not significantly benefit from conversion to LT. In addition, only one of four patients with chronic effusions had improvement of this condition after conversion. Despite the theoretic advantages of LT versus APA, persistence of atrial arrhythmias after conversion did occur. The one patient who died had atrial arrhythmias and another two patients had recurrence of atrial flutter, in one case early after operation and in the other 3 years later. Longer follow-up is therefore necessary before the effect of conversion on the incidence of arrhythmias can be determined.

The etiology of atrial tachycardias in these patients is still poorly defined. Possible contributing factors include (1) atrial scars (suture lines and cannulation sites), (2) increased atrial pressure or atrial dilation, and (3) sinus node dysfunction. Conversion to LT does not eliminate all of these issues and may even introduce new suture lines. Recent data from catheter ablation studies ${ }^{34}$ suggest that "zones of slow conduction" are present in the atrial wall of such patients, and these zones may not be eliminated simply by changing hemodynamics. As data accumulate from arrhythmia mapping and radiofrequency ablation, it may be possible to devise a surgical approach that involves surgical interruption of all potential slow zones, thereby eliminating the true substrate for these arrhythmias.

The most consistent clinical improvement occurred in patients with right pulmonary vein compression before conversion. This finding emphasizes the need for accurate hemodynamic assessment of patients with symptoms after APA or other modified Fontan procedures. Right pulmonary vein stenosis as a result of extrinsic compression by a dilated right atrium has not previously been reported, and its incidence among patients who have undergone Fon- 
tan operations is unknown. Pulmonary vein obstruction increases pulmonary vascular resistance, which would seem to be particularly detrimental in the setting of Fontan circulation. Patients with symptoms in whom this phenomenon is present are candidates for conversion to LT. This conclusion is supported by the pulmonary vein gradient relief and the improvement in symptoms achieved in our three patients.

All the patients in this study had a fenestration placed in the atrial baffle, a procedure previously shown to decrease early postoperative morbidity ${ }^{35}$ and mortality, although it may not necessarily influence long-term results. It is not possible to determine in this group of patients how much of the clinical improvement can be attributed to the presence of a fenestration. In three of the seven survivors the fenestration is now closed and these patients have shown sustained clinical improvement.

Limitations. The small number of patients in the study, their complex lesions, the absence of a control group, and the short follow-up period limit our ability to identify predictors of improvement with conversion to LT. In this retrospective study, selections of diagnostic tests and management were influenced by individual patient's physicians. Although evaluation of arrhythmias before conversion included 12-lead electrocardiography for all eight patients, Holter monitoring was carried out for only five patients and intracardiac electrophysiologic study was carried out for only two. Not every patient was catheterized after conversion, and postconversion hemodynamics were therefore not available in all cases. Additional surgical procedures were performed in some patients at the time of LT, and conversion to LT may thus not have been the only reason for clinical improvement.

Conclusions. Conversion from APA to a fenestrated LT is technically feasible and resulted in clinical improvement in some patients with symptoms after short term follow-up. It did not improve the conditions of those with protein-losing enteropathy, nor those of most with chronic effusions, suggesting that such patients may best be treated by direct cardiac transplantation rather than by conversion to LT. The procedure was successful for patients in whom a giant right atrium resulted in pulmonary vein compression, in all of whom the gradient was relieved. Attention to the possible diagnosis of right pulmonary vein stenosis is there- fore required because conversion to LT seems to particularly benefit these patients.

\section{REFERENCES}

1. Mair DM, Puga FG, Danielson GK. Late functional status of survivors of the Fontan procedure performed during the 1970s. Circulation 1992;82(Suppl):II106-9.

2. Peters NS, Somerville J. Arrhythmias after the Fontan procedure. Br Heart J 1992;68:199-204.

3. Balaji S, Gelling M, Bull C, de Leval MR, Deanfield JE. Arrhythmias after the Fontan operation: comparison of total cavopulmonary connection and atriopulmonary connection. Circulation 1991;84(Suppl):III162-7.

4. Behrendt DM, Rosenthal A. Cardiovascular status after repair by Fontan procedure. Ann Thorac Surg 1979;29:32230.

5. Gelatt M, Hamilton R, McCrindle BW, Gow RM, Williams WG, Trussler GA, et al. Risk factors for atrial tachyarrhythmias after the Fontan operation. J Am Coll Cardiol 1994;24: 1735-41.

6. Gewillig M, Wyse RK, de Leval MR, Deanfield JE. Early and late arrhythmias after the Fontan operation: predisposing factors and clinical consequences. Br Heart J 1991;67:72-9.

7. de Leval MR, Kilner P, Gewilling M, Bull C. Total cavopulmonary connection: a logical alternative to atriopulmonary connection for complex Fontan operations. J Thorac Cardiovasc Surg 1988;96:682-95.

8. Low HT, Chew YT, Lee CN. Flow studies on atriopulmonary and cavopulmonary connections of the Fontan operation for congenital heart defects. J Biomed Eng 1993;15:303-7.

9. Kao JM, Alejos JC, Grant PW, Williams RG, Shannon KM, Laks $\mathrm{H}$. Conversion of atriopulmonary to cavopulmonary anastomosis in management of late arrhythmias and atrial thrombosis. Ann Thorac Surg 1994;58:1510-4.

10. Mair DD, Hagler DJ, Puga FJ, Schaff HV, Danielson GK. Fontan operation in 176 patients with tricuspid atresia. Circulation 1990;82(Suppl):IV164-9.

11. Fontan F, Kirklin JW, Fernandez G, Costa F, Naftel DC, Tritto F, et al. Outcome after a "perfect" Fontan operation. Circulation 1990;81:1520-36.

12. Fernandez G, Costa F, Fontan F, Naftel DC, Blakstone EH, Kirklin JW. Prevalence of reoperation for pathway obstruction after Fontan operation. Ann Thorac Surg 1989;48:654-9.

13. Menkis AH, McKenzie FN, Novick RJ, Kostuk WJ, Pflufgelder PW, Goldbach M, et al. Expanding applicability of transplantation after multiple previous palliative procedures. The Pediatric Heart Transplant Group. Ann Thorac Surg 1991;52:722-6.

14. Cooper MM, Fuzesi L, Addonizio LJ, Hsu DT, Smith CR, Rose EA. Pediatric heart transplantation after operations involving the pulmonary arteries. J Thorac Cardiovasc Surg 1991;102:386-94.

15. Mayer JE Jr, Perry S, O'Brien P, Perez-Atayde A, Jonas RA, Castañeda AR, et al. Orthotopic heart transplantation for complex congenital heart disease. J Thorac Cardiovasc Surg 1990;99:484-91.

16. Kreutzer J, Perry SB, Keane JF, Mayer JE, Jonas RA, Lock JE. Catheter management of stenotic Fontan baffles and conduits [abstract]. J Am Coll Cardiol 1995;91:100A.

17. Fontan F, Baudet E. Surgical repair of tricuspid atresia. Thorax 1971;26:240-8. 
18. Kreutzer G, Galindez E, Bono H, de Palma C, Laura JP. Una operación para la corrección de la atresia tricuspidea. Ninth Argentinian Congress of Cardiology. Buenos Aires, Argentina. 1971 Oct 31-Nov 6.

19. Kreutzer G, Galindez E, Bono H, de Palma C, Laura JP. An operation for the correction of tricuspid atresia. $J$ Thorac Cardiovasc Surg 1973;85:647-58.

20. Gago O, Salles CA, Stern AM, Spooner E, Brandt RL, Morris JD. A different approach for the total correction of tricuspid atresia. J Thorac Cardiovasc Surg 1976;72:209-14.

21. Björk VO, Olin CL, Bjarke BB, Thorén CA. Right atrialright ventricular anastomosis for correction of tricuspid atresia. J Thorac Cardiovasc Surg 1979;77:452-8.

22. Gale AW, Danielson GK, McGoon DC, Mair DD. Modified Fontan operation for univentricular heart and complicated congenital lesions. J Thorac Cardiovasc Surg 1979;78:831-8.

23. Kreutzer GO, Vargas FJ, Schlichter AJ, Laura JP, Suarez JC, Coronel AR, et al. Atriopulmonary anastomosis. J Thorac Cardiovasc Surg 1982;83:427-36.

24. DeLeon SY, Ilbawi MN, Idriss FS, Backer CL, Ohtake S, Zales VR, et al. Direct tricuspid closure versus atrial partitioning in Fontan operation for complex lesions. Ann Thorac Surg 1989;47:761-4.

25. Chopra PS, Rao PS. Corrective surgery for tricuspid atresia: which modification of Fontan-Kreutzer procedure should be used? A review. Am Heart J 1992;123:758-67.

26. Pearl JM, Laks H, Stein DG, Drinkwater DC, George BL, Williams RG. Total cavopulmonary anastomosis versus conventional modified Fontan procedure. Ann Thorac Surg 1991;52:189-96.

27. Bridges ND, Lock JE, Castañeda AR. Baffle fenestration with subsequent transcatheter closure: modification of the Fontan operation for patients at increased risk. Circulation 1990;82:1681-9.

28. Laschinger JC, Ringel RE, Brenner JI, McLaughlin JS. Extracardiac total cavopulmonary connection. Ann Thorac Surg 1992;54:371-3.

29. Puga FJ, Chiavarelli M, Hagler DJ. Modifications of the Fontan operation applicable to patients with left atrioventricular valve atresia or single atrioventricular valve. Circulation 1987;76(3 Pt 2): $\Pi 1153-60$.

30. Jonas RA, Castañeda AR. Modified Fontan procedure: atrial baffle and systemic venous to pulmonary artery anastomotic techniques. J Card Surg 1988;3:91-6.

31. Murphy DA, Marble AE, Landymore R, Dajee H. Assessment of the isolated right atrium as a pump. J Thorac Cardiovasc Surg 1978;76:483-8.

32. Matsuda H, Kawashima Y, Takano H, Miyamoto K, Mori T. Experimental evaluation of atrial function in right atriumpulmonary artery conduit operations for tricuspid atresia. J Thorac Cardiovasc Surg 1981;81:762-7.

33. Gewillig M, Mertens L, Montas G, et al. Comparison of energy loss in different Fontan connections by computer modeling [abstract]. Circulation 1994;90:I254.

34. Treidman JK, Saul PS, Weindling SN, Walsh EP. Radiofrequency ablation of intraatrial reentrant tachycardia after surgical palliation of congenital heart disease. Circulation 1995;91:707-14.

35. Mayer JE Jr, Bridges ND, Lock JE, Hanley FL, Jonas RA, Castañeda AR. Factors associated with marked reduction in mortality for Fontan operations in patients with single ventricle. J Thorac Cardiovasc Surg 1992;103:444-52.

\section{Availability of Journal back issues}

As a service to our subscribers, copies of back issues of The Journal of Thoracic and Cardiovascular Surgery for the preceding 5 years are maintained and are available for purchase from the publisher, Mosby-Year Book, Inc., at a cost of $\$ 13.50$ per issue. The following quantity discounts are available: $25 \%$ off on quantities of 12 to 23, and one third off on quantities of 24 or more. Please write to Mosby-Year Book, Inc., Subscription Services, 11830 Westline Industrial Drive, St. Louis MO 63146-3318, or call 800-453-4351 or 314-453-4351 for information on availability of particular issues. If unavailable from the publisher, photocopies of complete issues are available from University Microfilms International, 300 N. Zeeb Rd., Ann Arbor, MI 48106, 313-761-4700. 